\title{
Ornithinicoccus hortensis gen. nov., sp. nov., a soil actinomycete which contains L-ornithine
}

\author{
Ingrid Groth, ${ }^{1}$ Peter Schumann, ${ }^{2}$ Karin Martin, ${ }^{1}$ Barbara Schuetze, ${ }^{1}$ \\ Kurt Augsten, ${ }^{3}$ Ina Kramer ${ }^{2}$ and Erko Stackebrandt ${ }^{2}$
}
1 Hans-Knöll-Institut für Naturstoff-Forschung e.V., D-07745 Jena, Germany
2 DSMZ-Deutsche Sammlung von Mikroorganismen und Zellkulturen $\mathrm{GmbH}$, D-38124 Braunschweig, Germany
3 Institut für Molekulare Biotechnologie e.V., D-07745 Jena, Germany

\author{
Author for correspondence: Ingrid Groth. Tel: +493641656666 . Fax : +493641656679 \\ e-mail: igroth@pmail.hki-jena.de
}

\begin{abstract}
Two Gram-positive coccoid, non-motile bacteria with L-ornithine as diagnostic diamino acid of the peptidoglycan and an interpeptide bridge of L-Orn $\leftarrow G_{(1,2)}$ $\leftarrow$ D-Glu were isolated from a sample of garden soil. The major menaquinone is MK-8 $\left(\mathrm{H}_{4}\right)$. 13-methyl and 12-methyl tetradecanoic acids are the predominant fatty acids. The polar lipids are phosphatidylinositol, phosphatidylglycerol, diphosphatidylglycerol, phosphatidylserine and two unknown phospholipids. Mycolic acids are absent. The DNA base composition is $72 \mathrm{~mol} \% \mathrm{G}+\mathrm{C}$. Recent comparative 16S rDNA studies revealed that strains HKI 0125' and HKI 0131 represent a novel lineage adjacent to the family Intrasporangiaceae of the order Actinomycetales but distinct from the previously described genera of this family. On the basis of the genotypic, chemotaxonomic, morphological and physiological characteristics of these two isolates it is proposed to classify HKI $0125^{\top}$ and HKI 0131 in a new genus and species for which the name Ornithinicoccus hortensis gen. nov., sp. nov. is proposed. The type strain is HKI $0125^{\top}$ ( = DSM 12335').
\end{abstract}

Keywords: Ornithinicoccus hortensis gen. nov., sp. nov., L-ornithine-containing actinomycete

\section{INTRODUCTION}

A few actinomycete genera contain ornithine as diagnostic diamino acid in their peptidoglycans. Those exhibiting peptidoglycans with cross-linkage A (Schleifer \& Kandler, 1972) are the genera Cellulomonas (Bergey et al., 1923) and Rarobacter (Yamamoto et al., 1988) belonging to the family Cellulomonadaceae. Genera having peptidoglycans with cross-linkage B are members of the family Microbacteriaceae, i.e. Curtobacterium (Yamada \& Komagata, 1972b) and Microbacterium (Orla-Jensen, 1919; Takeuchi \& Hatano, 1998), the latter of which now comprises members of the former genus Aureobacterium (Collins et al., 1983a,b; Yokota et al., 1993). The two families belong to the suborder Micrococcineae (Stackebrandt et al., 1997).

Of about 25 actinomycete isolates originating from a soil sample collected in a garden near Giessen (Germany), four strains were found having in common ornithine in the peptidoglycan and the respiratory

The EMBL accession numbers for the 16S rDNA sequences of Ornithinicoccus hortensis HKI $0125^{\top}$ and Rarobacter faecitabidus DSM $4813^{\top}$ are $Y 17869$ and $Y 17870$, respectively. menaquinones of the type $\mathrm{MK}-8\left(\mathrm{H}_{4}\right)$. This combination of significant diagnostic chemotaxonomic features has not been found before in actinomycetes as the ornithine containing genera are characterized by isoprenoid quinones MK-9 (Curtobacterium, Rarobacter), MK-10, MK-11, MK-12, MK-13, MK-14 (Microbacterium) and MK-9( $\left.\mathbf{H}_{4}\right)$ (Cellulomonas). By studying the morphological, physiological and chemotaxonomic characteristics of these four isolates we found that two of these strains should be placed in the same taxon because of the high similarity of their tested features. However, they differed remarkably from the other two isolates of the same origin (I. Groth, unpublished).

On the basis of our results presented in this study we conclude that strain HKI 0125 and HKI 0131 are phylogenetically identical and members of a new genus and a new species for which the name Ornithinicoccus hortensis is proposed. The type strain is HKI $0125^{\mathrm{T}}$ ( = DSM $\left.12335^{\mathrm{T}}\right)$.

\section{METHODS}

Bacterial strains and cultural conditions. Strains HKI $0125^{\mathrm{T}}$ and HKI 0131 were isolated from a soil sample collected in 


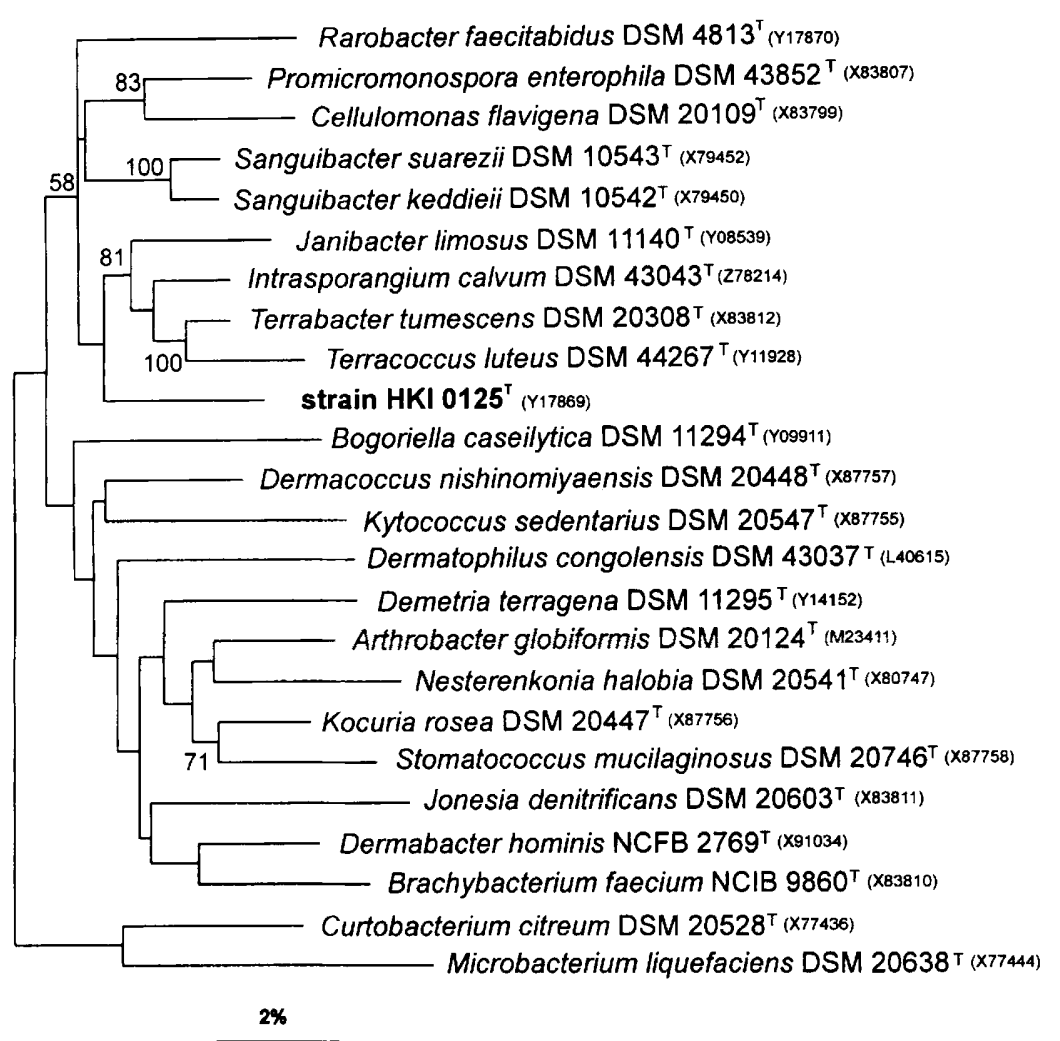

Fig. 1. 16S rDNA sequence-based phylogenetic dendrogram constructed from evolutionary distances (De Soete, 1983) showing the phylogenetic position of strain HKI $0125^{\top}$ next to members of the family Intrasporangiaceae and other families of the suborder Micrococcineae (Stackebrandt et al., 1997). Numbers at branching points refer to bootstrap values ( 500 trees resampled). Scale bar, two inferred nucleotide substititions per 100 nucleotides.

a garden near Giessen, Germany. One gram of soil was suspended in $10 \mathrm{ml}$ sterile phosphate buffer $(\mathrm{pH} \mathrm{7 \cdot 2)}$ and thoroughly mixed by shaking. Soil particles were allowed to sediment, the liquid phase was serially diluted and spread onto the surface of peptone/yeast extract/brain-heart infusion agar plates [PY-BHI medium (Yokota et al., 1993)] which contains per litre: $10 \mathrm{~g}$ peptone, $2 \mathrm{~g}$ yeast extract, $2 \mathrm{~g}$ brain-heart infusion, $2 \mathrm{~g} \mathrm{NaCl}$ and $2 \mathrm{~g}$ glucose $(\mathrm{pH} \mathrm{7} \cdot 2)$. Biomass for biochemical analyses was prepared by growing the strains in liquid rich (R) medium (Yamada \& Komagata, 1972a) and Bacto tryptic soy broth (Difco) and harvesting the cells by centrifugation. Solidified R medium was used for general laboratory cultivation and morphological and physiological studies unless otherwise indicated.

Morphological and physiological characteristics. Cell morphology was examined by phase-contrast microscopy (Olympus BH-2 microscope). Motility was studied by the hanging drop technique. Cell dimensions were measured microscopically [Olympus BX 50, combined with the image analysing software VIS $5504 \mathrm{H}$ (Jentech)]. Gram staining and acid-fast staining were performed as described previously (Groth et al., 1997). For scanning electron microscopy a 24 -h-old culture grown on a $\mathrm{R}$ agar plate was suspended in phosphate buffer ( $\mathrm{pH} 7 \cdot 2)$. Preparation of cells was as described by Groth et al. (1997). Cell morphology was studied with a field emission scanning electron microscope (LED 1530) with a working distance of $3 \mathrm{~mm}$. Colony morphology was studied with a stereo microscope (Olympus SZ 11). Growth dependence on different incubation temperatures, increasing concentrations of $\mathrm{NaCl}$ in the culture medium and on the supply with oxygen, as well as the utilization of various organic compounds and selected enzyme activities, were studied as described by Groth et al. (1997). The susceptibility to antibiotics was tested by placement of antibiotic discs (Oxoid) on $\mathrm{R}$ agar plates seeded with suspensions of HKI $0125^{\mathrm{T}}$ and HKI 0131, respectively.

Cell wall analysis. Purified cell wall preparations were obtained by the method of Schleifer \& Kandler (1972). The amino acids and peptides in cell wall hydrolysates were analysed by two-dimensional ascending TLC on cellulose plates using the solvent systems of Schleifer \& Kandler (1972). The amino terminal amino acid of the interpeptide bridge was determined by dinitrophenylation as described by Schleifer (1985). Whole-cell sugars were determined as alditol acetates by GC as described by Groth et al. (1996). The molar ratios of amino acids were determined by GC and GC-MS of $N$-heptafluorobutyryl amino acid isobutyl esters (MacKenzie, 1987). Analysis of enantiomers of cell wall amino acids was performed by GC of $N$-pentafluoropropionyl amino acid isopropyl esters (Frank et al., 1980) on a L-Chirasil-Val column $(25 \mathrm{~m} \times 0.25 \mathrm{~mm}$ i.d.; MachereyNagel) using helium as carrier gas at a linear velocity of $200 \mathrm{~mm} \mathrm{~s}^{-1}$ and at a temperature programmed from 80 to $190{ }^{\circ} \mathrm{C}$ at a rate of $2^{\circ} \mathrm{C} \mathrm{min}^{-1}$. Instruments used for $\mathrm{GC}$ and GC-MS were as specified previously (Groth et al., 1996). The glycolate content of bacterial cell walls was determined by the colorimetric method of Uchida \& Aida (1984).

Lipid analysis. Cellular fatty acid methyl esters obtained from cells grown in Bacto tryptic soy broth at $28^{\circ} \mathrm{C}$ by the method of Stead et al. (1992) were separated by GC (Groth et al., 1996) and identified as described previously (Schumann et al., 1997). Menaquinones were extracted as described by Collins et al. (1977) and were analysed by HPLC (Groth et al., 1997). Polar lipids extracted by the method of Minnikin et al. (1979) were identified by twodimensional TLC and spraying with specific reagents 
(Collins \& Jones, 1980). Absence of mycolic acids was demonstrated by TLC (Minnikin et al., 1975).

DNA base composition. DNA was isolated and its $\mathrm{G}+\mathrm{C}$ content determined by HPLC of deoxyribonucleosides as described by Groth et al. (1996).

16S rDNA sequence determination and phylogenetic analysis. Preparation of genomic DNA from strains HKI $0125^{\mathrm{T}}$ and HKI 0131 was done as described previously (Rainey et al., 1996). Sequences were aligned manually with sequences published previously. These were stored in the DSMZ database consisting of several thousand $16 \mathrm{~S}$ rDNA sequence entries, including those from the Ribosomal Database Project (Maidak et al., 1997) and EMBL. Similarity values were transformed into phylogenetic distance values that compensate for multiple substitutions at any given site in the sequence (Jukes \& Cantor, 1969). The algorithm of De Soete (Maidak et al., 1997) and the neighbour-joining method contained in the PHYLIP package (Felsenstein, 1993) were used in the construction of phylogenetic dendrograms. Bootstrap values were determined according to Felsenstein (1993). All analyses were done on a SUN SparcII workstation.

Nucleotide accession numbers. The accession numbers of the reference strains used in the phylogenetic analysis are shown in Fig. 1.

\section{RESULTS}

\section{Morphological and physiological characteristics}

The strains HKI $0125^{\mathrm{T}}$ and HKI 0131 were very similar in colony and cell morphology. They mainly formed cream-coloured, circular, glistening, opaque colonies with an entire margin on $\mathrm{R}$ medium. However, a few colonies were observed having a depressed centre surrounded by a uniform or radial structured wall and

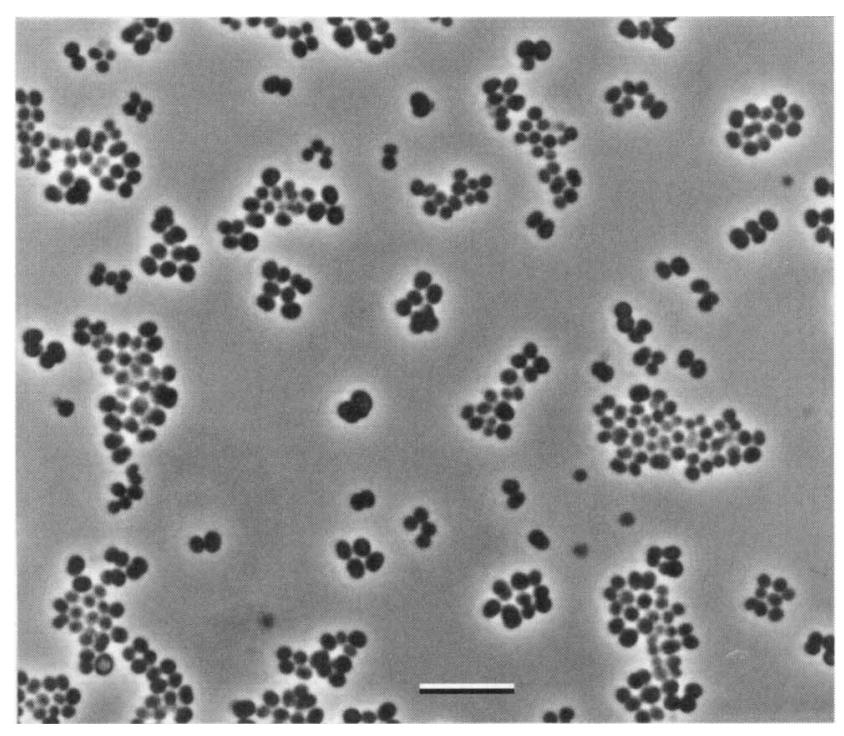

Fig. 2. Micrograph of strain HKI $0125^{\top}$ grown on R agar for $6 \mathrm{~d}$ at $28^{\circ} \mathrm{C}$. Bar, $10 \mu \mathrm{m}$.

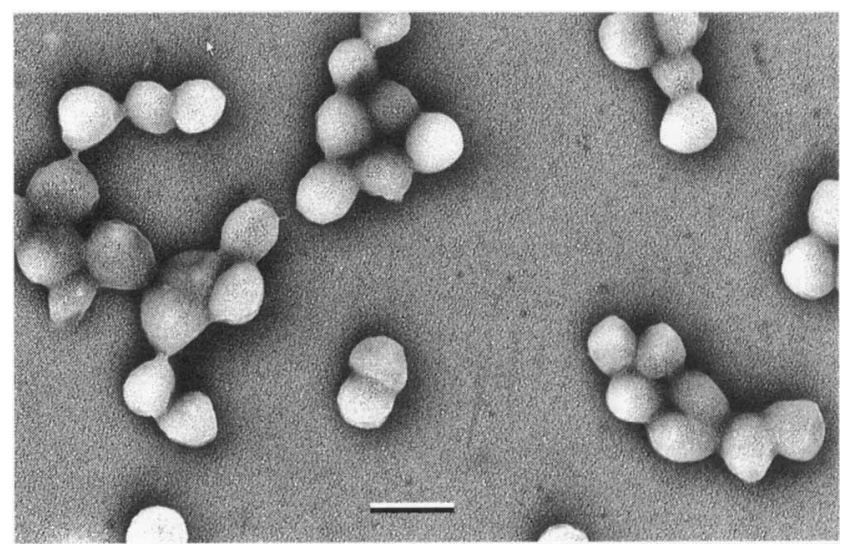

Fig. 3. Scanning electron micrograph of cells from a 24-h-old culture of strain $\mathrm{HKI} 0125^{\top}$ grown on R agar. Bar, $1 \mu \mathrm{m}$.

an irregular wrinkly marginal zone. The colony sizes were in the range $0.6-4.3 \mathrm{~mm}$. Cells were irregularly spherical, occurring singly, in pairs, short chains and in clusters (Figs 2 and 3 ). The cell diameters varied from 0.8 to $1.3 \mu \mathrm{m}$. Spore formation and motility of the cells were not observed.

Both strains grew well on complex organic media under aerobic and microaerophilic conditions. No growth occurred in an anaerobic atmosphere. Optimal temperatures for growth were 28 to $37^{\circ} \mathrm{C}$. At a temperature of $42^{\circ} \mathrm{C}$ the strains did not grow. $\mathrm{NaCl}$ in combination with $\mathrm{R}$ medium was tolerated up to a concentration of $4 \%(\mathrm{w} / \mathrm{v})$. Addition of $6 \%(\mathrm{w} / \mathrm{v})$ of $\mathrm{NaCl}$ to the culture medium resulted in a strong decrease in growth. At concentrations of $8 \%(\mathrm{w} / \mathrm{v})$ and $10 \%(\mathrm{w} / \mathrm{v})$ of $\mathrm{NaCl}$ only traces of growth were observed and at a concentration of $12 \%(\mathrm{w} / \mathrm{v})$ of $\mathrm{NaCl}$ growth was completely inhibited. Liquid cultures of both strains were maintained at $-80^{\circ} \mathrm{C}$ and in the vapour phase of liquid nitrogen. The latter is recommended for long-term storage.

The cells of strains HKI $0125^{\mathrm{T}}$ and HKI 0131 were Gram-positive and not acid-fast.

The physiological properties are listed in Table 1. Both isolates HKI $0125^{\mathrm{T}}$ and HKI 0131 were very similar in most of the tested characteristics. The acid production from carbohydrates was in the case of positive reactions (Table 1) generally low and indicated an oxidative metabolism. On aesculin-iron agar both strains produced a brown pigment after a prolonged incubation time of more than $7 \mathrm{~d}$. This pigment was different from the black staining of the agar in the case of positive aesculin hydrolysis. It stained the colonies and penetrated into the agar. Sodium malate was readily used as sole carbon source while disodium succinate, sodium formate and sodium aconitate were utilized after a prolonged incubation time (about $7 \mathrm{~d}$ ). HKI $0125^{\mathrm{T}}$ and HKI 0131 were susceptible to all 
Table 1. Physiological properties of strains HKI $0125^{\top}$ and HKI 0131

- , Negative; + , positive; $w$, weakly positive.

\begin{tabular}{|c|c|c|c|c|c|c|c|c|}
\hline Test & $\begin{array}{l}\text { HKI } \\
0125^{T}\end{array}$ & $\begin{array}{c}\text { HKI } \\
0131\end{array}$ & Test & $\begin{array}{l}\text { HKI } \\
0125^{\mathrm{T}}\end{array}$ & $\begin{array}{c}\text { HKI } \\
0131\end{array}$ & Test & $\begin{array}{l}\text { HKI } \\
0125^{T}\end{array}$ & $\begin{array}{c}\text { HKI } \\
0131\end{array}$ \\
\hline \multicolumn{3}{|l|}{ Decomposition of: } & \multicolumn{3}{|l|}{ Utilization of: } & \multicolumn{3}{|l|}{ Growth in the presence of: } \\
\hline Adenine & - & - & Acetate & - & w & $2 \% \mathrm{NaCl}$ & + & + \\
\hline Casein & + & + & Aconitate & + & + & $4 \% \mathrm{NaCl}$ & + & + \\
\hline Aesculin & - & - & Benzoate & - & - & $6 \% \mathrm{NaCl}$ & w & w \\
\hline Gelatin & + & + & Citrate & - & + & $8 \% \mathrm{NaCl}$ & w & w \\
\hline Hippurate & w & + & Formate & + & $\mathrm{w}$ & $10 \% \mathrm{NaCl}$ & w & w \\
\hline Hypoxanthine & + & + & Malate & + & + & $12 \% \mathrm{NaCl}$ & - & - \\
\hline Potato starch & - & - & Succinate & + & + & Antibiotic susceptibility: & & \\
\hline Tween 80 & + & + & DL-Tartrate & - & - & Ampicillin, $10 \mu \mathrm{g}$ & + & + \\
\hline Tyrosine & - & - & Enzyme assay (API ZYM) & & & Chloramphenicol, $30 \mu \mathrm{g}$ & + & + \\
\hline Urea & - & w & Phosphatase alkaline & + & + & Ciprofloxacin, $5 \mu \mathrm{g}$ & + & + \\
\hline Xanthine & + & + & Esterase (C 4) & + & + & Erythromycin, $15 \mu \mathrm{g}$ & + & + \\
\hline \multicolumn{3}{|c|}{ Acid produced from: } & Esterase lipase (C 8) & + & + & Gentamicin, $10 \mu \mathrm{g}$ & + & + \\
\hline L-Arabinose & - & - & Lipase (C 14) & $\mathrm{w}$ & + & Kanamycin, $30 \mu \mathrm{g}$ & + & + \\
\hline Lactose & - & - & Leucine arylamidase & + & + & Lincomycin, $2 \mu \mathrm{g}$ & + & w \\
\hline D-Cellobiose & - & - & Valine arylamidase & w & + & Neomycin, $30 \mu \mathrm{g}$ & + & + \\
\hline Dextrin & + & w & Cystine arylamidase & + & + & Nitrofuran, $300 \mu \mathrm{g}$ & + & + \\
\hline D-Fructose & + & - & Trypsin & - & - & Oxacillin, $5 \mu \mathrm{g}$ & - & $\mathbf{w}$ \\
\hline D-Galactose & - & - & Chymotrypsin & + & + & Oxytetracycline, $30 \mu \mathrm{g}$ & + & + \\
\hline D-Glucitol & w & w & Phosphatase acid & w & w & Penicillin G, 2 IU & + & + \\
\hline D-Glucose & + & $\mathrm{w}$ & Naphthol-AS-BI- & + & w & Polymyxin B, $300 \mathrm{IU}$ & + & + \\
\hline Glycerol & w & - & phosphohydrolase & & & Rifampin, $2 \mu \mathrm{g}$ & + & + \\
\hline Inulin & - & - & $\alpha$-Galactosidase & - & - & Streptomycin, $10 \mu \mathrm{g}$ & + & + \\
\hline Maltose & + & w & $\beta$-Galactosidase & - & - & Sulfonamide, $300 \mu \mathrm{g}$ & - & - \\
\hline D-Mannitol & w & $\mathrm{w}$ & $\beta$-Glucuronidase & - & - & Nitrate reduction & + & + \\
\hline D-Mannose & w & - & $\alpha$-Glucosidase & + & + & Production of $\mathrm{H}_{2} \mathrm{~S}$ & + & + \\
\hline D-Raffinose & - & - & $\beta$-Glucosidase & - & - & Catalase reaction & + & + \\
\hline L-Rhamnose & - & - & $N$-Acetyl- $\beta$-glucosamidase & - & - & Methyl red test & - & - \\
\hline D-Ribose & - & - & $\alpha$-Mannosidase & - & - & Voges-Proskauer test & - & - \\
\hline Salicin & - & - & $\alpha$-Fucosidase & - & - & Oxidase test & - & - \\
\hline Sucrose & w & $\mathrm{w}$ & Growth at: & & & Indole test & - & - \\
\hline Potato starch & + & + & $28^{\circ} \mathrm{C}$ & + & + & & & \\
\hline Trehalose & w & w & $37^{\circ} \mathrm{C}$ & + & + & & & \\
\hline D-Xylose & - & - & $42^{\circ} \mathrm{C}$ & - & - & & & \\
\hline
\end{tabular}

antibiotics tested except sulfonamide. They were strongly inhibited by penicillin $\mathrm{G}$, chloramphenicol, erythromycin and rifampin.

\section{Cell wall analysis}

The peptidoglycan of strains HKI $0125^{\mathrm{T}}$ and HKI 0131 contained Orn, Ala, Glu and Gly in a molar ratio of $0 \cdot 8: 1 \cdot 5: 2 \cdot 0: 1 \cdot 6$ (HKI $0131,1 \cdot 0: 1 \cdot 6: 2 \cdot 0: 1 \cdot 7$ ), respectively. Dinitrophenylated Glu and traces of dinitrophenylated Gly were detected in hydrolysates of cell wall preparations treated with 1-fluoro-2,4-dinitrobenzene. Enantiomeric analysis of cell wall amino acids resulted in detection of L-Orn, D-Ala, L-Ala, DGlu and L-Glu (traces). From these results and from two-dimensional thin-layer chromatographic peptide patterns of partial hydrolysates of cell walls (data not shown), it was concluded that strains HKI $0125^{\mathrm{T}}$ and HKI 0131 contain a peptidoglycan of type $A 4 \beta$ (Schleifer \& Kandler, 1972) with an L-Orn $\leftarrow$ Gly $_{(1,2)}$ $\leftarrow$ D-Glu interpeptide bridge. The acyl type was acetyl. Glucose was found as only whole-cell sugar.

\section{Lipid analysis}

The polar lipid patterns consisted of phosphatidylinositol, phosphatidylglycerol, diphosphatidylglycerol, phosphatidylserine and two unknown phospholipids. The cellular fatty acid profiles (Table 2 ) were of the iso and anteiso branched type and were 
Table 2. Cellular fatty acid composition (\%) of strains HKI $0125^{\top}$ and HKI 0131

The abbreviations for fatty acids are illustrated by the following examples: $\mathrm{C}_{16: 0}$, hexadecanoic acid; $\mathrm{C}_{18: 1}$, octadecenoic acid; $\mathrm{i}-$ $\mathrm{C}_{15: 0}$, 13-methyl tetradecanoic acid; ai- $\mathrm{C}_{17: 0}, 14-$-methyl hexadecanoic acid.

\begin{tabular}{|c|c|c|c|c|c|c|c|c|c|c|c|c|c|c|c|c|c|c|c|c|}
\hline Strain & $\mathrm{i}-\mathrm{C}_{13: 0}$ & $a i-C_{13: 0}$ & $\mathrm{i}-\mathrm{C}_{14: 0}$ & $C_{14: 0}$ & $\mathrm{i}-\mathrm{C}_{15: 0}$ & $\mathrm{i}-\mathrm{C}_{15: 1}$ & ai- $C_{15}$ & $\mathrm{C}_{15: 0}$ & $C_{15: 1}$ & $\mathrm{i}-\mathrm{C}_{16: 0}$ & $\mathrm{i}-\mathrm{C}_{16: 1}$ & $C_{16: 0}$ & $C_{16: 1}$ & $\mathbf{i}-\mathbf{C}_{17: 0}$ & ai- $C_{170}$ & $\mathrm{i}-\mathrm{C}_{17: 1}$ & $C_{17: 0}$ & $C_{17: 1}$ & $C_{18: 0}$ & $C_{1 x: 1}$ \\
\hline HKI $0125^{\mathrm{T}}$ & 0.7 & 0.4 & $0 \cdot 9$ & $3 \cdot 1$ & 36.6 & $3 \cdot 6$ & $19 \cdot 4$ & 8.5 & & 3.5 & $0 \cdot 4$ & $4 \cdot 7$ & $1.0 ?$ & $1 \cdot 3$ & 30 & 5.5 & & & & 0.8 \\
\hline HKI 0131 & 0.5 & $0 \cdot 2$ & $0 \cdot 3$ & 0.6 & $46 \cdot 6$ & $4 \cdot 5$ & 16.8 & $4 \cdot 1$ & 02 & $2 \cdot 2$ & $0 \cdot 2$ & 1.4 & 0.5 & 2.6 & $3 \cdot 3$ & $10-1$ & $0 \cdot 2$ & 0.2 & $0 \cdot 1$ & 0.8 \\
\hline
\end{tabular}

distinctly dominated by the occurrence of 13-methyl and 12-methyl tetradecanoic acids.

The major menaquinone was $\mathrm{MK}-8\left(\mathrm{H}_{4}\right)$. MK-8 $\left(\mathrm{H}_{2}\right)$ occurred in minor amounts. Strain HKI $0125^{\mathrm{T}}$ showed MK-6( $\left.\mathrm{H}_{4}\right)$ and strain HKI 0131 showed MK-9( $\left.\mathrm{H}_{2}\right)$ and MK-8 as additional minor components. Mycolic acids were not present.

\section{DNA base composition}

Strains HKI $0125^{\mathrm{T}}$ and HKI 0131 had a DNA G $+\mathrm{C}$ content of $72 \mathrm{~mol} \%$.

\section{S rDNA analyses}

Phylogenetic information on Rarobacter faecitabidus DSM $4813^{\mathrm{T}}$ had already been incorporated into the analysis of the class Actinobacteria (Stackebrandt et al., 1997), without, however, having deposited the $16 \mathrm{~S}$ rDNA sequence. The EMBL number is Y17870.

The almost complete 16S rDNA sequence was determined for strain HKI $0125^{\mathrm{T}}$. The $5^{\prime}$ terminal 500 nucleotides of strain HKI 0131 were identical with those of strain HKI $0125^{\mathrm{T}}$. Comparison of the sequence of strain HKI $0125^{\mathrm{T}}$ with those of the class Actinobacteria revealed that this strain is a phylogenetic member of the suborder Micrococcineae (Stackebrandt et al., 1997), with which strain HKI $0125^{\mathrm{T}}$ shared between 90 and $95 \%$ similarity. The highest similarity values, ranging between 94.5 and $95.2 \%$ were found with members of the genera Janibacter, Intrasporangium and Terrabacter while those obtained with Terracoccus luteus and some members of the genera Cellulomonas, Sanguibacter and Kytococcus were slightly lower $(92 \cdot 1-94.0 \%$ similarity).

Assessment of the phylogenetic position of strain HKI $0125^{\mathrm{T}}$ within the radiation of a varying selection of reference organisms, using the algorithms of De Soete (Maidak et al., 1997) and the neighbour-joining method (Felsenstein, 1993), consistently showed this strain to branch adjacent to Janibacter and certain genera of the family Intrasporangiaceae, i.e. Intrasporangium, Terrabacter and Terracoccus (Fig. 1). The position of neighbouring genera, however, changed with the algorithms applied. While according to the neighbour-joining algorithm the neighbouring cluster contains members of the family Dermatophilaceae (not shown), the distance matrix analysis of De Soete indicates that the phylogenetic neighbours are members of Sanguibacter and Cellulomonadaceae (Fig. 1). In none of the trees the genus Sanguibacter, described to be a member of the family Intrasporangiaceae, and sharing the same set of signature nucleotides, clustered with the other members of the family. As noted before (Stackebrandt et al., 1997) almost none of the branching points among actinobacterial families is supported by high bootstrap values; this phenomenon extends even to some intrafamily relationships when the radiation of lineages occurs within a short evolutionary time span.

\section{DISCUSSION}

Both isolates under study showed $100 \%$ homology in their 16S rDNA sequences. Therefore strain HKI 0131 was considered to be a member of the same species as HKI $0125^{\mathrm{T}}$. This affiliation was confirmed by the high similarity in morphological, physiological and chemotaxonomic characteristics. The minor differences we stated however in various properties between the two isolates are an expression of phenotypic variation within the species and indicate that the strains despite of the same origin are not identical.

The results of the 16S rDNA sequence comparison show clearly that strain HKI $0125^{\mathrm{T}}$ forms a distinct clade neighbouring the evolutionary radiation of the family Intrasporangiaceae and Janibacter limosus. The question whether strain HKI $0125^{\mathrm{T}}$ should be considered a member of the family Intrasporangiaceae could be decided upon the presence of family signature nucleotides in the sequence of HKI $0125^{\mathrm{T}}$. Of the 17 signatures described for the genera Sanguibacter, Terrabacter and Intrasporangium, only 12 signatures are present in the sequence of HKI $0125^{\mathrm{T}}$. Janibacter limosus, a taxon that branches intermediate to strain HKI $0125^{\mathrm{T}}$ and members of the family Intrasporangiaceae, possessed only 13 of the 17 familyspecific signatures. These significant differences may indicate that neither strain HKI $0125^{\mathrm{T}}$ nor Janibacter limosus should be considered as members of the family Intrasporangiaceae. At this point a decision about higher taxon affiliation should await analysis of additional strains of both taxa.

The phylogenetic separateness of Janibacter and strain HKI $0125^{\mathrm{T}}$ from Intrasporangiaceae is extended to the epigenetic level. Members of this family contain LL$\mathrm{A}_{2} \mathrm{pm}$ in their peptidoglycans, the structure of which is unique within members of the suborder Micrococcineae (Prauser et al., 1997). On the other hand, the 
Table 3. Differential characteristics of strain $\mathrm{HKI} 0125^{\top}$ and related taxa

Abbreviations: D-Orn, D-ornithine; L-Orn, L-ornithine; meso-A ${ }_{2} \mathrm{pm}$, meso-diaminopimelic acid; LL-A ${ }_{2}$ pm, LL-diaminopimelic acid; DPG, diphosphatidylglycerol; GL, unknown glycolipid(s); PE, phosphatidylethanolamine; PG, phosphatidylglycerol; PGL, unknown phosphoglycolipid; PI, phosphatidylinositol; PIM, phosphatidylinositolmannoside; PSer, phosphatidylserine; PLs, unknown phospholipids; A, anteiso methyl-branched; I, iso methyl-branched; S, straight-chain saturated; U, monounsaturated; ND, not determined.

\begin{tabular}{|c|c|c|c|c|c|c|c|}
\hline Taxon & Cell morphology & $\begin{array}{l}\text { Wall diamino } \\
\text { acid }\end{array}$ & $\begin{array}{c}\text { G+C content } \\
(\mathrm{mol} \%)\end{array}$ & Murein type & Major menaquinone(s) & Polar lipid & Fatty acid type \\
\hline HKI $0125^{\mathrm{T}}$ & Cocci, non-motile & L-Orn & 72 & $A 4 \beta$ & $\mathrm{MK}-8\left(\mathrm{H}_{4}\right)$ & PI, PG, DPG, PSer, PLs & $\mathrm{S}, \mathrm{A}, \mathrm{I}$ \\
\hline Cellulomonas* & $\begin{array}{l}\text { Irregular rods, motile or } \\
\text { non-motile }\end{array}$ & L-Orn & $71-76$ & $\mathrm{~A} 4 \beta$ & MK-9( $\left.\mathrm{H}_{4}\right)$ & DPG, PI, PGL & S, A, I \\
\hline Rarobacter $\dagger, \ddagger$ & Rods & L-Orn & $65-66$ & $\mathrm{~A} 4 \beta$ & MK-9 & ND & S, A, I \\
\hline Curtobacterium $\dagger$ & Irregular rods, motile & D-Orn & $68-75$ & $\mathrm{~B} 2 \beta$ & MK-9 & DPG, PG, Gls & S, A, I \\
\hline Microbacterium $\neq, \S$ & Irregular rods & D-Orn, L-Lys & $67-70$ & $\mathrm{~B} 2 \beta, \mathrm{B} 2 \alpha$ & MK-11, MK-12, MK-13, MK-14 & DPG, PG, GL & $\mathrm{S}, \mathrm{A}, \mathrm{I}$ \\
\hline Intrasporangium $\|$ & Hyphae & $\mathrm{LL}-\mathrm{A}_{2} \mathrm{pm}$ & 68 & $\mathrm{~A} 3 \gamma$ & MK-8 & PI, PIM, PG, DPG & $\mathrm{S}, \mathrm{A}, \mathrm{I}$ \\
\hline Terrabacter & Rod/coccus cycle & $\mathrm{LL}-\mathrm{A}_{2} \mathrm{pm}$ & $70-73$ & $\mathrm{~A} 3 \gamma$ & $\mathrm{MK}-8\left(\mathrm{H}_{4}\right)$ & DPG, PI, PE, PL & $\mathrm{S}, \mathrm{A}, \mathrm{I}$ \\
\hline Terracoccus\# & Cocci in packets, non-motile & $L \mathbf{L}-\mathrm{A}_{2} \mathrm{pm}$ & 73 & $\mathrm{~A} 3 \gamma$ & MK- $-8\left(\mathrm{H}_{4}\right)$ & PE, PI, PG, DPG & $\mathrm{S}, \mathrm{A}, \mathrm{I}$ \\
\hline Janibacter & Coccoid to rod-shaped, non-motile & $m e s o-A_{2} p m$ & 70 & $\mathrm{~A} 1 \gamma$ & $\mathrm{MK}-8\left(\mathrm{H}_{4}\right)$ & DPG, PG, PI & $\mathrm{S}, \mathrm{I}, \mathrm{U}$ \\
\hline
\end{tabular}

* Data from Stackebrandt et al. (1995).

$\uparrow$ Data from Yokota et al. (1993).

† Data from Goto-Yamamoto et al. (1993).

$\S$ Data from Takeuchi \& Hatano (1998).

|l Data from Schumann et al. (1997).

- Data from Martin et al. (1997).

\# Data from Prauser et al. (1997).

peptidoglycans of strains HKI $0125^{\mathrm{T}}$ and HKI 0131 contain L-ornithine while Janibacter limosus possesses $m e s o-\mathrm{A}_{2} \mathrm{pm}$ as the diagnostic diamino acid (Martin $e t$ al., 1997). Other differences in taxonomically important diagnostic features are shown in Table 3.

Strains HKI $0125^{\mathrm{T}}$ and HKI 0131 are assumed to be a novel taxon among members of the peptidoglycan A type-containing Actinobacteria because of the unusual combination of $\mathrm{L}$-ornithine as diagnostic diamino acid in the peptidoglycan and the presence of tetrahydrogenated menaquinones with eight isoprene units as predominant isoprenologue. In contrast to the two ornithine-containing peptidoglycan A type genera Rarobacter and Cellulomonas, strains HKI $0125^{\mathrm{T}}$ and HKI 0131 possess peptidoglycan variation $A 4 \beta$ (Schleifer \& Kandler, 1972) defined by an L-Orn $\leftarrow$ Gly $_{(1,2)} \leftarrow \mathrm{D}$-Glu interpeptide bridge. This type has not yet been described before in Actinobacteria. This feature and additional chemotaxonomic, morphological and physiological characteristics (Table 3 ) justify a separation of our two isolates on the genus level from the above-mentioned genera. The moderate degree of phylogenetic relatedness to the two members of the family Cellulomonadaceae confirms our results (Fig. 1). While peptidoglycan A-type organisms are common in actinomycetes and encompass several separate phylogenetic lineages it was shown that B-type organisms are more closely related among each other, comprising the family Microbacteriaceae (Park et al., 1993; Rainey et al., 1994; Takeuchi \& Yokota, 1994; Stackebrandt et al., 1997). It is pointed out in the dendrogram that strain HKI $0125^{\mathrm{T}}$ is unrelated to the ornithine-containing genera Curtobacterium and Microbacterium. This is supported by chemotaxonomic features as well as morphological and physiological characteristics. On the basis of the distinct phylogenetic position at the basis of the family Intrasporangiaceae and the pronounced differences in morphological, physiological and chemotaxonomic characteristics we propose that the genus Ornithinicoccus should be established for the strains HKI $0125^{\mathrm{T}}$ and HKI 0131. The type species of the genus Ornithinicoccus is Ornithinicoccus hortensis gen. nov., sp. nov., which is represented by type strain HKI $0125^{\mathrm{T}}$ and strain HKI 0131 which are deposited in the DSMZ as DSM $12335^{\mathrm{T}}$ and DSM 12336, respectively.

\section{Description of Ornithinicoccus gen. nov.}

Ornithinicoccus (or'ni.thi.ne. Gr. n. ornithos bird, ornithine an amino acid named after birds; Gr. n. coccos a grain; M.L. masc. n. Ornithinicoccus a coccus with ornithine).

Cells are irregularly spherical occurring singly, in pairs, short chains and clusters. Cell diameters vary from 0.8 to $1.3 \mu \mathrm{m}$. Gram-positive, not acid-fast, non-motile, no formation of spores. Aerobic to microaerophilic. Oxidase-negative, catalase-positive. The peptidoglycan type is $\mathrm{A} 4 \beta$ with $\mathrm{L}$-Orn $\leftarrow \mathrm{Gly}_{(1,2)} \leftarrow \mathrm{D}$-Glu as interpeptide bridge. The acyl type is acetyl. The major menaquinone is $\mathrm{MK}-8\left(\mathrm{H}_{4}\right)$. The major fatty acids are 13-methyl and 12-methyl tetradecanoic acids. The polar lipids are phosphatidylinositol, phosphatidylglycerol, diphosphatidylglycerol, phosphatidylserine 
and two unknown phospholipids. The $\mathrm{G}+\mathrm{C}$ content of the DNA is $72 \mathrm{~mol} \%$. Phylogenetically this genus is a member of the suborder Micrococcineae in which it is closely related to members of the family Intrasporangiaceae (Stackebrandt et al., 1997). The type species is Ornithinicoccus hortensis.

\section{Description of Ornithinicoccus hortensis sp. nov.}

Ornithinicoccus hortensis (hor.ten'sis. L. masc. n. hortus garden; M.L. adj. hortensis referring to the place where the organism was isolated).

Cells are irregularly spherical occurring singly, in pairs, short chains and clusters. Cell diameters vary from 0.8 to $1.3 \mu \mathrm{m}$. Gram-positive, not acid-fast, non-motile, no formation of spores. Aerobic to microaerophilic. Oxidase-negative, catalase-positive. Colonies are $0 \cdot 6$ $4.3 \mathrm{~mm}$ in diameter, cream coloured, circular, convex with an entire or structured surface and marginal zone. Acids produced in a low amount from D-glucose, maltose, D-mannitol, D-glucitol, trehalose, starch, dextrin, sucrose. No acid production from L-arabinose, lactose, D-cellobiose, D-galactose, inulin, D-raffinose, L-rhamnose, D-ribose, salicin and D-xylose. Acid production is variable from D-fructose, glycerol and Dmannose. Aconitate, formate, malate and succinate are used as sole carbon sources. Utilization of acetate and citrate is variable. Benzoate and DL-tartrate are not utilized. Nitrate is reduced to nitrite, $\mathrm{H}_{2} \mathrm{~S}$ and catalase are produced, indole and oxidase are not produced. Methyl red and Voges-Proskauer reactions are negative. Casein, gelatin, hippurate, hypoxanthine, xanthin and Tween 80 are decomposed; aesculin and tyrosin are not decomposed. Urease activity is variable. $\mathrm{NaCl}$ in combination with $\mathrm{R}$ medium is well tolerated up to a concentration of $4 \%$. Good growth occurs at 28 and $37^{\circ} \mathrm{C}$; no growth at $42{ }^{\circ} \mathrm{C}$. Cells are susceptible to ampicillin $(10 \mu \mathrm{g})$, chloramphenicol $(30 \mu \mathrm{g})$, ciprofloxacin $(5 \mu \mathrm{g})$, erythromycin $(15 \mu \mathrm{g})$, gentamicin $(10 \mu \mathrm{g})$, kanamycin $(30 \mu \mathrm{g})$, neomycin $(30 \mu \mathrm{g})$, nitrofuran $(300 \mu \mathrm{g})$, oxytetracycline $(30 \mu \mathrm{g})$, penicillin G (2 IU), polymyxin B (300 IU), rifampin $(2 \mu \mathrm{g})$ and streptomycin $(10 \mu \mathrm{g})$. Susceptibility to oxacillin $(5 \mu \mathrm{g})$ is unclear, no susceptibility to sulfonamide. Tested by the API ZYM enzyme assay HKI $0125^{\mathrm{T}}$ and HKI 0131 are positive for phosphatase alkaline, esterase (C 4), esterase lipase (C 8), lipase (C 14), leucine arylamidase, valine arylamidase, cystine arylamidase, chymotrypsin, phosphatase acid, naphthol-AS-BI-phosphohydrolase, $\alpha$-glucosidase and negative for trypsin, $\alpha$-galactosidase, $\beta$-galactosidase, $\beta$-glucuronidase, $\beta$-glucosidase, $N$-acetyl- $\beta$-glucosamidase, $\alpha$-mannosidase, $\alpha$-fucosidase. The peptidoglycan is of the A4 $\beta$-type with an L-Orn $\leftarrow \mathrm{Gly}_{(1,2)} \leftarrow$ D-Glu as interpeptide bridge. The acyl type is acetyl. The fatty acid pattern is of the iso and anteiso branched type. The major menaquinone $\mathrm{MK}-8\left(\mathrm{H}_{4}\right)$. The polar lipids are phosphatidylinositol, phosphatidylglycerol, diphosphatidylglycerol, phosphatidylserine and two unknown phospholipids. Glucose is the only whole-cell sugar. The $\mathrm{G}+\mathrm{C}$ content of the DNA is
$72 \mathrm{~mol} \%$. Mycolic acids are absent. The habitat is soil. The type strain is HKI $0125^{\mathrm{T}}$ which has been deposited in the DSMZ as DSM $12335^{\text {T }}$.

\section{ACKNOWLEDGEMENTS}

We acknowledge Jutta Meyer for critical reading of the manuscript.

We thank Christiane Weigel and Carmen Schult for excellent technical assistance and Fred Rainey for sequence analysis of Rarobacter faecitabidus DSM $4813^{\mathrm{T}}$.

\section{REFERENCES}

Bergey, D. H., Harrison, F. C., Breed, R. S., Hammer, B. W. \& Huntoon, F. M. (editors) (1923). Bergey's Manual of Determinative Bacteriology. Baltimore: Williams \& Wilkins.

Collins, M. D. \& Jones, D. (1980). Lipids in the classification and identification of coryneform bacteria containing peptidoglycans based on 2,4-diaminobutyric acid. $J$ Appl Bacteriol 48, 459-470.

Collins, M. D., Pirouz, T., Goodfellow, M. \& Minnikin, D. E. (1977). Distribution of menaquinones in actinomycetes and corynebacteria. $J$ Gen Microbiol 100, 221-230.

Collins, M. D., Jones, D., Keddie, R. M., Kroppenstedt, R. M. \& Schleifer, K. H. (1983a). Classification of some coryneform bacteria in a new genus Aureobacterium. Syst Appl Microbiol 4, 236-252.

Collins, M. D., Jones, D., Keddie, R. M., Kroppenstedt, R. M. \& Schleifer, K. H. (1983b). Aureobacterium gen. nov. In Validation of the Publication of New Names and New Combinations Previously Effectively Published Outside the IJSB, List no. 11. Int $J$ Syst Bacteriol 33, 672-674.

De Soete, G. (1983). A least square algorithm for fitting additive trees to proximity data. Psychometrika 48, 621-626.

Felsenstein, J. (1993). PHYLIP (Phylogenetic Inference Package) version 3.5.1. Seattle: Department of Genetics, University of Washington.

Frank, H., Rettenmeier, A., Weicker, H., Nicholson, G. J. \& Bayer., E. (1980). A new gas chromatographic method for determination of amino acid levels in human serum. Clin Chim Acta 105, 201-211.

Goto-Yamamoto, N., Sato, S.-I., Miki, H., Park, Y. K. \& Tadenuma, M. (1993). Taxonomic studies on yeast-lysing bacteria, and a new species Rarobacter incanus. J Gen Appl Microbiol 39, 261-272.

Groth, I., Schumann, P., Weiss, N., Martin, K. \& Rainey, F. A. (1996). Agrococcus jenensis gen. nov., sp. nov., a new genus of actinomycetes with diaminobutyric acid in the cell wall. Int $J$ Syst Bacteriol 46, 234-239.

Groth, I., Schumann, P., Rainey, F. A., Martin, K., Schuetze, B. \& Augsten, K. (1997). Demetria terragena gen. nov., sp. nov., a new genus of actinomycetes isolated from compost soil. Int $J$ Syst Bacteriol 47, 1129-1133.

Jukes, T. H. \& Cantor, C. R. (1969). Evolution of protein molecules. In Mammalian Protein Metabolism, vol. 3, pp. 21-132. Edited by H. N. Munro. New York: Academic Press.

MacKenzie, S. L. (1987). Gas chromatographic analysis of amino acids as the $N$-heptafluorobutyryl isobutyl esters. $J$ Assoc Off Anal Chem 70, 151-160.

Maidak, B. L., Larsen, N., McCaughey, M. J., Overbeek, R., Olsen, G. J. \& Woese, C. R. (1997). The ribosomal database project. Nucleic Acids Res 25, 109-111. 
Martin, K., Schumann, P., Rainey, F. A., Schuetze, B. \& Groth, I. (1997). Janibacter limosus gen. nov., sp. nov., a new actinomycete with meso-diaminopimelic acid in the cell wall. Int $J$ Syst Bacteriol 47, 529-534.

Minnikin, D. E., Alshamaony, L. \& Goodfellow, M. (1975). Differentiation of Mycobacterium, Nocardia, and related taxa by thin-layer chromatographic analysis of whole-organism methanolysates. J Gen Microbiol 88, 200-204.

Minnikin, D. E., Collins, M. D. \& Goodfellow, M. (1979). Fatty acid and polar lipid composition in the classification of Cellulomonas, Oerskovia and related taxa. J Appl Bacteriol 47, 87-95.

Orla-Jensen, S. (1919). The Lactic Acid Bacteria. Copenhagen: Host.

Park, Y.-H., Suzuki, K.-I., Yim, D.-G. \& 7 other authors (1993). Suprageneric classification of peptidoglycan group B actinomycetes by nucleotide sequencing of $5 \mathrm{~S}$ ribosomal RNA. Antonie Leeuwenhoek 64, 307-313.

Prauser, H., Schumann, P., Rainey, F. A., Kroppenstedt, R. M. \& Stackebrandt, E. (1997). Terracoccus luteus gen. nov., sp. nov., an LL-diaminopimelic acid-containing coccoid actinomycete from soil. Int J Syst Bacteriol 47, 1218-1224.

Rainey, F. A., Weiss, N., Prauser, H. \& Stackebrandt, E. (1994). Further evidence for the phylogenetic coherence of actinomycetes with group B-peptidoglycan and evidence for the phylogenetic intermixing of the genera Microbacterium and Aureobacterium as determined by $16 \mathrm{~S}$ rDNA analysis. FEMS Microbiol Lett 118, 135-139.

Rainey, F. A., Ward-Rainey, N., Kroppenstedt, R. M. \& Stackebrandt, E. (1996). The genus Nocardiopsis represents a phylogenetically coherent taxon and a distinct actinomycete lineage: proposal of Nocardiopsaceae fam. nov. Int $J$ Syst Bacteriol 46, 1088-1092.

Schleifer, K. H. (1985). Analysis of the chemical composition and primary structure of murein. Methods Microbiol 18, 123-156.

Schleifer, K. H. \& Kandler, O. (1972). Peptidoglycan types of bacterial cell walls and their taxonomic implications. Bacteriol Rev 36, 407-477.

Schumann, P., Prauser, H., Rainey, F. A., Stackebrandt, E. \& Hirsch, P. (1997). Friedmanniella antarctica gen. nov., sp. nov., an LL-diaminopimelic acid-containing actinomycete from Antarctic sandstone. Int $J$ Syst Bacteriol 47, 278-283.

Stackebrandt, E., Koch, C., Gvozdiak, O. \& Schumann, P. (1995). Taxonomic dissection of the genus Micrococcus: Kocuria gen. nov., Nesterenkonia gen. nov., Kytococcus gen. nov., and Micrococcus Cohn 1872 gen. emend. Int J Syst Bacteriol 45, 682-692.

Stackebrandt, E., Rainey, F. A. \& Ward-Rainey, N. (1997). Proposal for a new hierarchic classification system, Actinobacteria classis nov. Int $J$ Syst Bacteriol 47, 479-491.

Stead, D. E., Sellwood, J. E., Wilson, J. \& Viney, I. (1992). Evaluation of a commercial microbial identification system based on fatty acid profiles for rapid, accurate identification of plant pathogenic bacteria. J Appl Bacteriol 72, 315-321.

Takeuchi, M. \& Hatano, K. (1998). Union of the genera Microbacterium Orla-Jensen and Aureobacterium Collins et al. in a redefined genus Microbacterium. Int J Syst Bacteriol 48, 739-747.

Takeuchi, M. \& Yokota, A. (1994). Phylogenetic analysis of the genus Microbacterium based on 16S rRNA gene sequences. FEMS Microbiol Lett 124, 11-16.

Uchida, K. \& Aida, K. (1984). An improved method for the glycolate test for simple identification of the acyl type of bacterial cell walls. J Gen Appl Microbiol 30, 131-134.

Yamada, K. \& Komagata, K. (1972a). Taxonomic studies on coryneform bacteria. IV. Morphological, cultural, biochemical, and physiological characteristics. J Gen Appl Microbiol 18, 399-416.

Yamada, K. \& Komagata, K. (1972b). Taxonomic studies on coryneform bacteria. V. Classification of coryneform bacteria. $J$ Gen Appl Microbiol 18, 417-431.

Yamamoto, N., Sato, S.-I., Saito, K., Hasuo, T., Tadenuma, M., Suzuki, K.-I., Tamaoka, J. \& Komagata, K. (1988). Rarobacter faecitabidus gen. nov., sp. nov., a yeast-lysing coryneform bacterium. Int J Syst Bacteriol 38, 7-11.

Yokota, A., Takeuchi, M., Sakane, T. \& Weiss, N. (1993). Proposal of six new species of the genus Aureobacterium and transfer of Flavobacterium esteraromaticum Omelianski to the genus Aureobacterium as Aureobacterium esteraromaticum comb. nov. Int J Syst Bacteriol 43, 555-564. 